\title{
The Coexistence of Symbiosis and Pathogenicity-Determining Genes in Rhizobium rhizogenes Strains Enables Them to Induce Nodules and Tumors or Hairy Roots in Plants
}

\author{
Encarna Velázquez, ${ }^{1}$ Alvaro Peix, ${ }^{2}$ José Luis Zurdo-Piñeiro, ${ }^{1}$ José Luis Palomo, ${ }^{3}$ Pedro F. Mateos, ${ }^{1}$ \\ Raúl Rivas, ${ }^{1}$ Estefanía Muñoz-Adelantado, ${ }^{4}$ Nicolás Toro, ${ }^{4}$ Pablo García-Benavides,${ }^{3}$ and \\ Eustoquio Martínez-Molina ${ }^{1}$
}

${ }^{1}$ Departamento de Microbiología y Genética, Universidad de Salamanca, Spain; ${ }^{2}$ Instituto de Recursos Naturales y Agrobiología, IRNA-CSIC, Salamanca, Spain; ${ }^{3}$ Centro de Diagnóstico de la Junta de Castilla y León, Salamanca, Spain; ${ }^{4}$ Estación Experimental del Zaidín, CSIC, Granada, Spain

Submitted 16 March 2005. Accepted 31 August 2005.

\begin{abstract}
Bacteria belonging to the family Rhizobiaceae may establish beneficial or harmful relationships with plants. The legume endosymbionts contain nod and nif genes responsible for nodule formation and nitrogen fixation, respectively, whereas the pathogenic strains carry vir genes responsible for the formation of tumors or hairy roots. The symbiotic and pathogenic strains currently belong to different species of the genus Rhizobium and, until now, no strains able to establish symbiosis with legumes and also to induce tumors or hairy roots in plants have been reported. Here, we report for the first time the occurrence of two rhizobial strains $\left(163 \mathrm{C}\right.$ and $\left.\mathrm{ATCC} 11325^{\mathrm{T}}\right)$ belonging to Rhizobium rhizogenes able to induce hairy roots or tumors in plants and also to nodulate Phaseolus vulgaris under natural environmental conditions. Symbiotic plasmids (pSym) containing nod and nif genes and pTi- or pRi-type plasmids containing vir genes were found in these strains. The nodD and nifH genes of the strains from this study are phylogenetically related to those of Sinorhizobium strains nodulating $P$. vulgaris. The $\operatorname{vir} A$ and $\operatorname{vir} B 4$ genes from strain $163 \mathrm{C}$ are phylogenetically related to those of $R$. tumefaciens $\mathrm{C58}$, whereas the same genes from strain ATCC $11325^{\mathrm{T}}$ are related to those of hairy root-inducing strains. These findings may be of high relevance for the better understanding of plantmicrobe interactions and knowledge of rhizobial phylogenetic history.
\end{abstract}

The family Rhizobiaceae contains bacteria able to induce nodules in legumes as well as bacteria able to produce hairy

Corresponding author: Encarna Velázquez; Telephone: +34 923 294532; Fax: +34 923 224876; E-mail: evp@usal.es

Nucleotide sequence data is available in the GenBank database under the following accession numbers: 16S rRNA gene sequences, AY206687 (strain 163c) and AY945955 (Rhizobium rhizogenes ATCC 11325 $5^{\mathrm{T}}$ ); virA sequences, AY945951 (strain 163C) and AY945952 (R. rhizogenes ATCC $11325^{\mathrm{T}}$ ); virB4 sequences, DQ092358 (strain 163C) and DQ092359 $(R$. rhizogenes ATCC $11325^{\mathrm{T}}$ ); nifH sequences, AY945950 (strain 163C) and AY945954 ( $R$. rhizogenes ATCC $\left.11325^{\mathrm{T}}\right)$; and nodD sequences, AY945949 (strain 163C) and AY945953 (R. rhizogenes ATCC11325 $5^{\mathrm{T}}$ ). roots or plant tumors. Initially, these two types of bacteria were classified in two different genera, named Rhizobium and Agrobacterium, respectively. The recent reclassification of genus Agrobacterium into genus Rhizobium (Young et al. 2001) has changed the taxonomic structure of family Rhizobiaceae, although many authors do not agree with the new classification because there are molecular and phenotypic data which support the separation of both genera (Farrand et al. 2003). The current taxonomic classification of the family Rhizobiaceae members is based on their 16S rRNA sequences and is not related with their ability to establish different plant-microbe relationships. Nevertheless, in the current genus Rhizobium, the strains able to induce tumors or hairy roots are classified in different species than those able to induce nodules (Young et al. 2001). The strains nodulating legumes from the genera Rhizobium and Sinorhizobium carry plasmids (pSym) containing nod and nif genes responsible for the nodulation and nitrogen fixation, respectively. The plant-pathogenic strains carry plasmids containing vir genes, named pTi and pRi in tumorigenic and hairy root-inducing strains, respectively. The nodD and nifH genes present a suitable degree of conservation among rhizobia and have been used for several phylogenetic studies (Hauka et al. 1998; Laguerre et al. 2001; Rivas et al. 2002; Suominen et al. 2001). The nodD gene is involved in the regulation of nod genes by the nod-box (van Rhijn et al. 1993), and the nifH codifies for the ferroprotein monomer of nitrogenase. The $\operatorname{vir} A$ is a regulatory gene whose sequence is well conserved in pathogenic strains of Rhizobium tumefaciens and $R$. rhizogenes (Endoh et al. 1990; Jin et al. 1990; Lee et al. 1995; Satuti et al. 2000). The virB4 is also an essential gene for virulence (Berger and Christie 1993, Dang and Christie 1997 ) included in the virB operon present in pathogenic species of the genus Rhizobium.

Until now, natural strains carrying symbiotic and pathogenicity-determining genes and able to produce nodules and pathogenic symptoms were unknown. In this article, we report for the first time two strains, $163 \mathrm{C}$ and $R$. rhizogenes ATCC $11325^{\mathrm{T}}$, able to produce tumors in Lycopersicon esculentum (Velázquez et al. 2001b) and to induce hairy roots in plants (Kersters et al. 1973), respectively, which also can nodulate Phaseolus vulgaris. 


\section{RESULTS}

\section{S rRNA sequence analysis.}

In a previous study, we showed that the low molecular weight (LMW) RNA profile of strain 163C resembles that of ATCC $11325^{\mathrm{T}}$ and that, therefore, these two strains were considered as belonging to the same species (Velázquez et al., 2001b). Nevertheless, because the current bacterial phylogeny and taxonomy are based on 16S rRNA gene sequences, these sequences were obtained from strains $163 \mathrm{C}$ and ATCC $11325^{\mathrm{T}}$. The phylogenetic analysis based on the nearly complete $16 \mathrm{~S}$
rRNA sequences (Fig. 1) shows the placement of strain 163C in the phylogenetic group of $R$. rhizogenes. A pairwise analysis of the 16S rRNA gene sequences of strains $163 \mathrm{C}$ and ATCC $11325^{\mathrm{T}}$ displayed $99.9 \%$ identity indicating that, in agreement with the results previously obtained by LMW RNA profiling, strain $163 \mathrm{C}$ should belong to $R$. rhizogenes.

\section{Plasmid profiling and DNA hybridization.}

As explained above, the symbiosis and pathogenicity-determining genes in species from genus Rhizobium are codified in plasmids. The plasmid analysis of strains $163 \mathrm{C}$ (Fig. 2, lane 2)

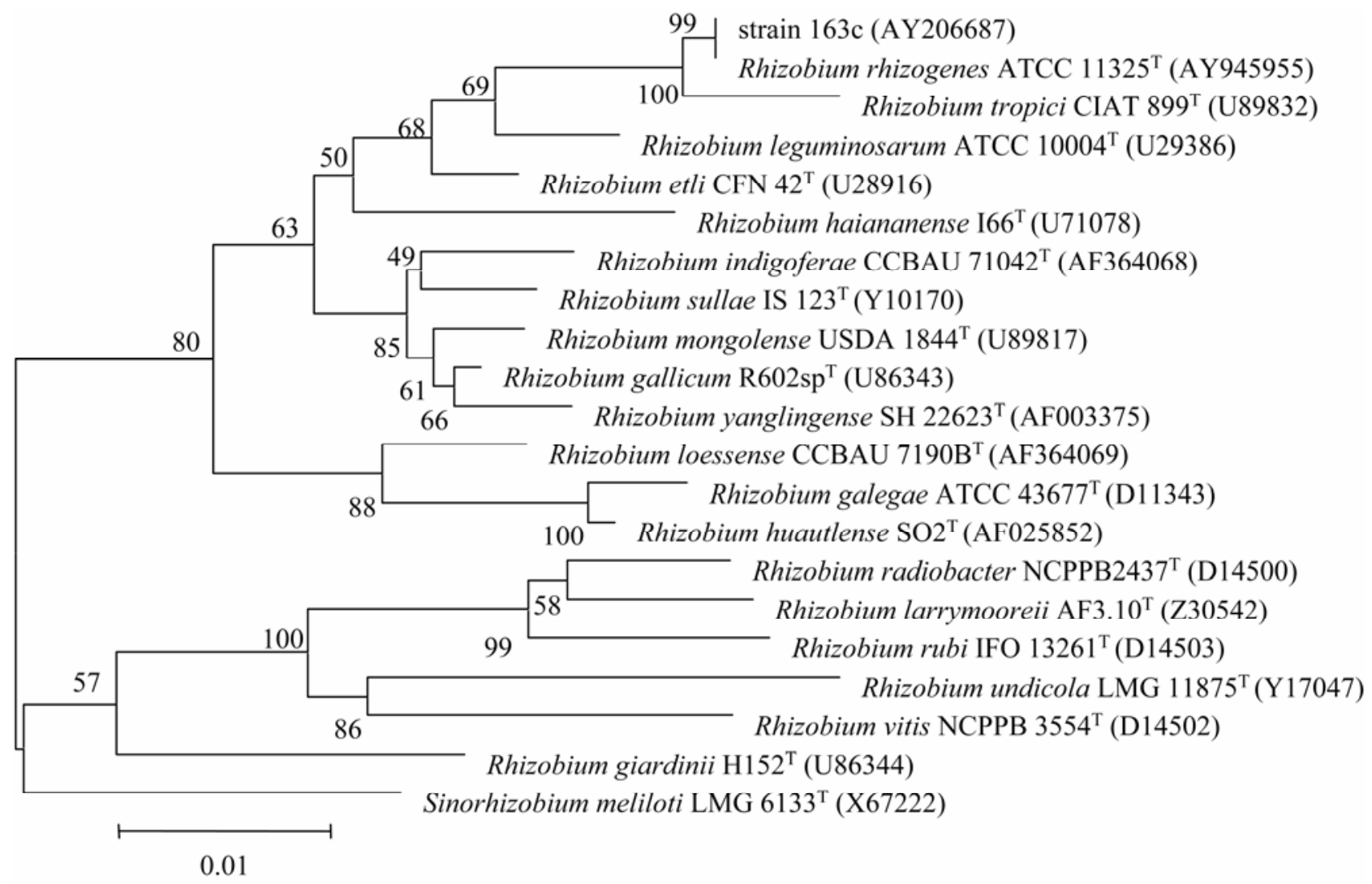

Fig. 1. Neighbor-joining tree based on nearly complete $16 \mathrm{~S}$ rRNA gene sequences of species belonging to the family Rhizobiaceae. Bootstrap values calculated for 1,000 replications are indicated. Bar, 1 nucleotide substitution per 100 nucleotides.

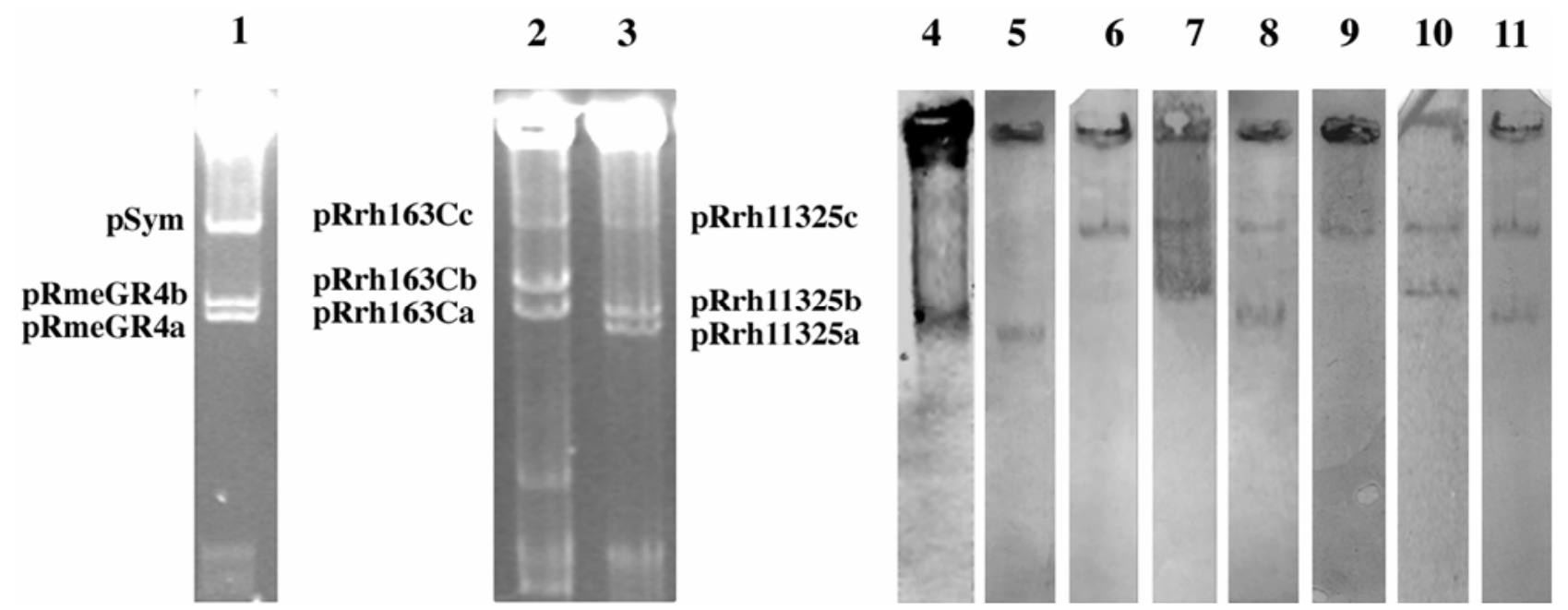

Fig. 2. Plasmid profile in horizontal $0.7 \%$ agarose gel: Sinorhizobium meliloti GR4 (lane 1), strain 163C (lane 2), and ATCC 11325 ${ }^{\mathrm{T}}$ (lane 3). Results of the hybridization using virA probe: strains $163 \mathrm{C}$ (lane 4) and ATCC $11325^{\mathrm{T}}$ (lane 5); nodD probe: strain GR4 (lane 6), strain 163C (lane 7), and ATCC 11325 (lane 8); and nifH probe: strain GR4 (lane 9), strain 163C (lane 10), and ATCC 11325 (lane 11). 
and ATCC $11325^{\mathrm{T}}$ (Fig. 2, lane 3) revealed three megaplasmids in each strain. Both strains have a megaplasmid of similar size, greater than $1,700 \mathrm{~kb}$ (pRrh163Cc and pRrh11325c). The plasmids pRrh $163 \mathrm{Cb}$ and pRrh163Ca present in strain 163C are approximately 320 and $190 \mathrm{~kb}$ in size, respectively. Strain ATCC $11325^{\mathrm{T}}$ has two plasmids of approximately $180 \mathrm{~kb}$ (pRrh11325b) and $120 \mathrm{~kb}$ (pRrh11325a).

To test the presence of virA loci in strains 163C and ATCC $11325^{\mathrm{T}}$, we performed a Southern blot using a virA probe. The hybridization data revealed that the pRrh163Ca and pRrh11325a plasmids present in the strains studied contain this gene (Fig. 2, lanes 4 and 5). No hybridization was found using this probe in the remaining plasmids of the strains analyzed or in Sinorhizobium meliloti GR4 used as reference (data not shown). Because this probe hybridized with only one of the plasmids present in the strains considered and they are phylogenetically related with nodulating-legume species of the genus Rhizobium, we also tested whether any of the plasmids contain symbiotic genes. The results of Southern blot hybridization using nodD and nifH probes show that homologous genes (Fig. 2) are located in the plasmids pRrh163Cb and pRrh163Cc carried by strain 163C and pRrh11325b and pRrh $11325 \mathrm{c}$ carried by ATCC $11325^{\mathrm{T}}$. Thus, it seems that these strains harbor both types of plasmids, pTi and pSym (strain 163C), or pRi and pSym (strain ATCC $11325^{\mathrm{T}}$ ).

\section{Sequencing of $\operatorname{vir} A, \operatorname{vir} B 4, \operatorname{nodD}$, and nifH genes from strain $163 \mathrm{C}$.}

Partial sequences of these genes were obtained and analyzed in order to define their phylogenetic position in relation to those of other related species. The virA gene sequence of strain $163 \mathrm{C}$ was $99.9 \%$ similar to the virA gene from $R$. tumefaciens C58, a tumorigenic strain whose complete genome has been recently sequenced (Goodner et al. 2001). The virA gene of strain ATCC $11325^{\mathrm{T}}$ was phylogenetically divergent from that of strain 163C (Fig. 3) and closely related (89.6\% similarity) to that of strain $R$. rhizogenes $\mathrm{A} 4$, which is able to induce hairy roots in plants (Endoh et al. 1990, Liang et al. 1998). The virB4 gene of strain ATCC $11325^{\mathrm{T}}$ showed $89.6 \%$ similarity to that of $R$. rhizogenes A4 (Fig. 4). The virB4 sequence of strain $163 \mathrm{C}$ again was closely related to that of strain C58 $(99.7 \%$ similarity).

The nifH genes of strains $163 \mathrm{C}$ and ATCC $11325^{\mathrm{T}}$ showed $100 \%$ identity between them and with respect to the nifH of Sinorhizobium sp. GR-06 and GR-X8, two strains isolated from P. vulgaris in Spain (Herrera-Cervera et al. 1999) (Fig. $5)$. The sequences of nodD genes from strains $163 \mathrm{C}$ and ATCC $11325^{\mathrm{T}}$ were closely related, but not identical $(96.3 \%$ similarity), their closest relative being the nodD gene of Sinorhizobium sp. BR816, a strain with broad host range able to nodulate $P$. vulgaris, and Leucaena and Trifolium spp. (Hernández-

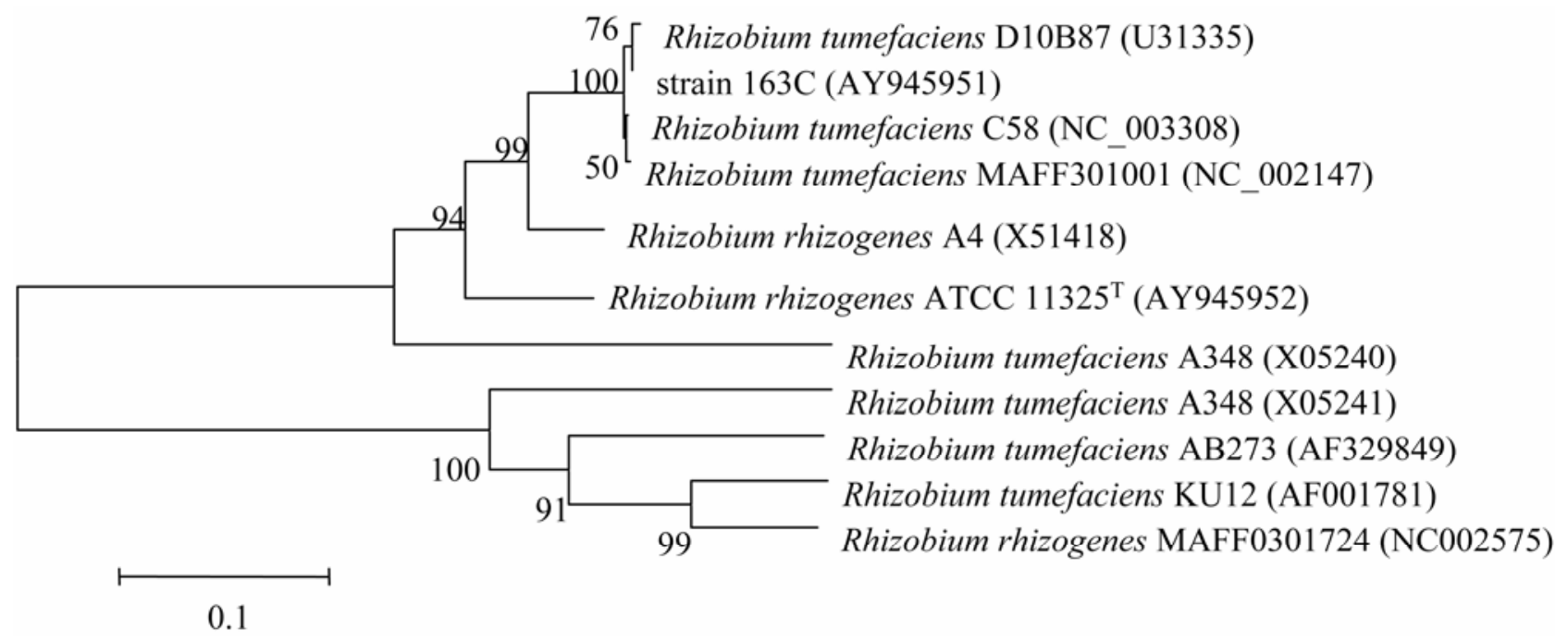

Fig. 3. Neighbor-joining tree of virA gene sequences of the strains analyzed in this study and representative related strains from GenBank. Bootstrap values calculated for 1,000 replications are indicated. The analysis was based on 300 nucleotides. Bar, 1 nucleotide substitution per 100 nucleotides.

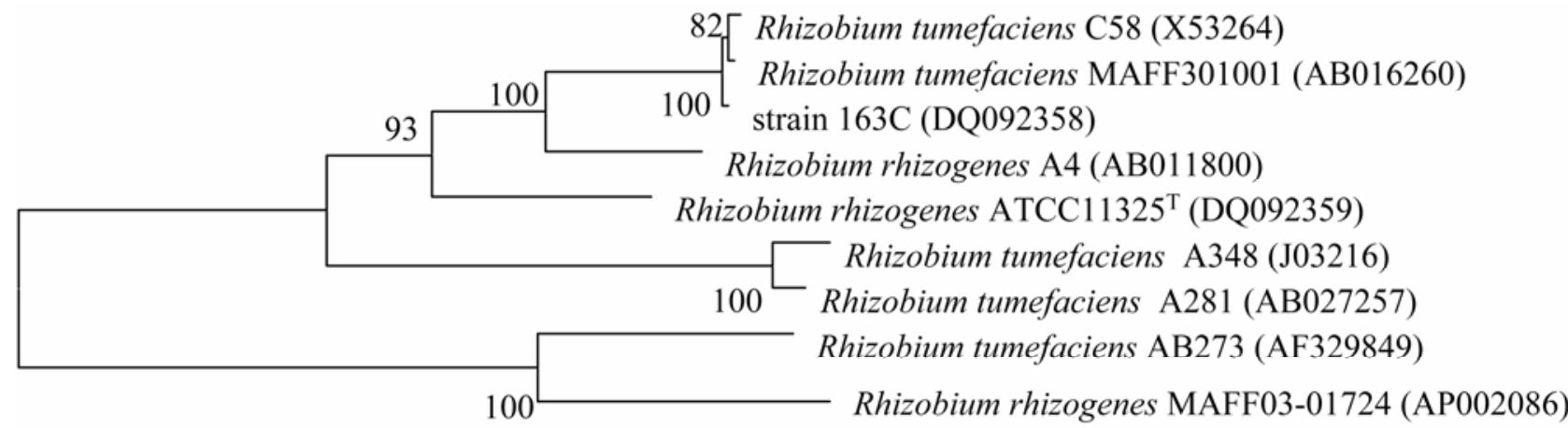

0.05

Fig. 4. Neighbor-joining tree of virB4 gene sequences of the strains analyzed in this study and representative related strains from GenBank. Bootstrap values calculated for 1,000 replications are indicated. The analysis was based on 1,130 nucleotides. Bar, 5 nucleotide substitutions per 100 nucleotides. 


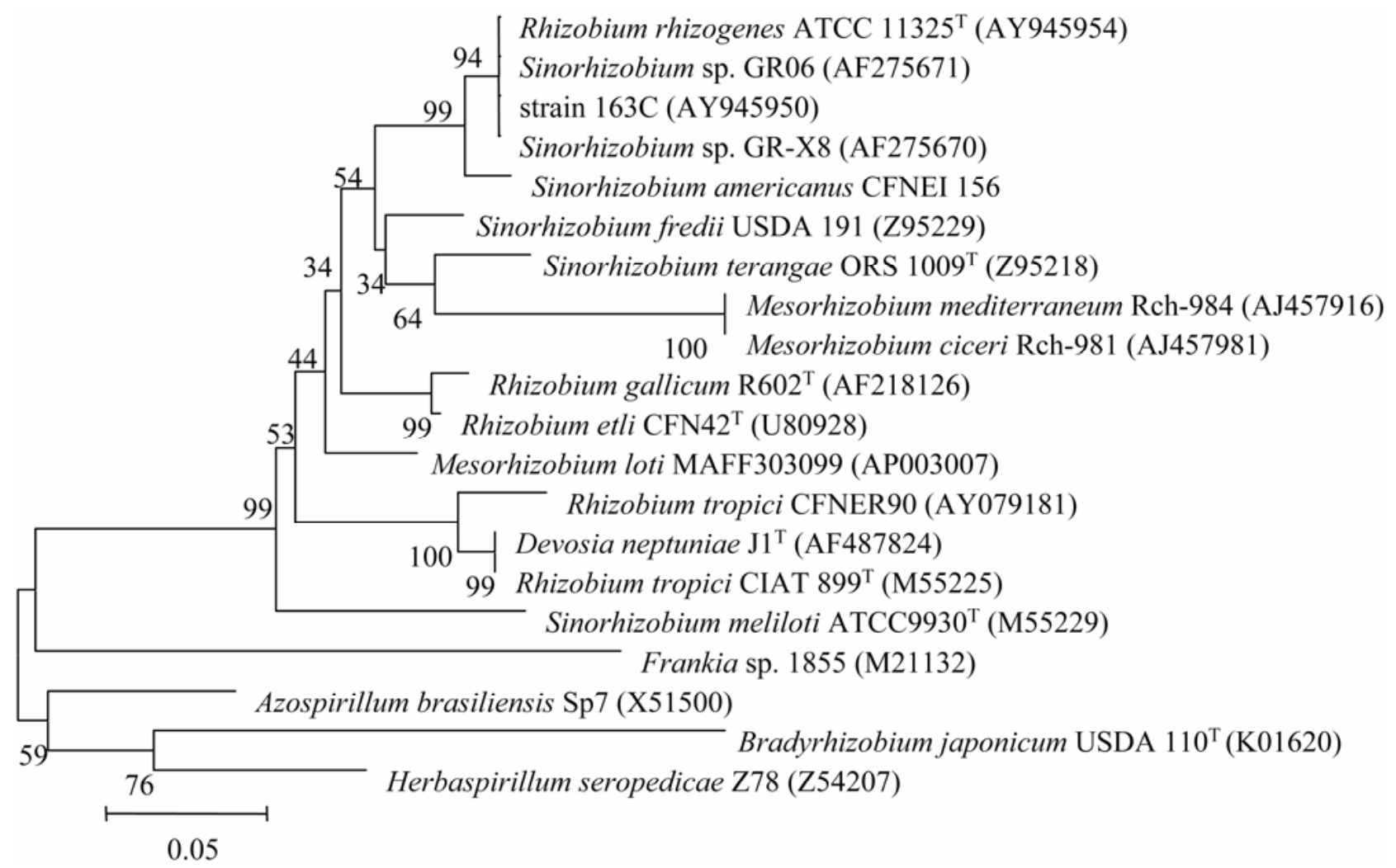

Fig. 5. Neighbor-joining tree of nifH gene sequences of the strains analyzed in this study and representative related strains from GenBank. Bootstrap values calculated for 1,000 replications are indicated. The analysis was based on 344 nucleotides. Bar, 5 nucleotide substitutions per 100 nucleotides.

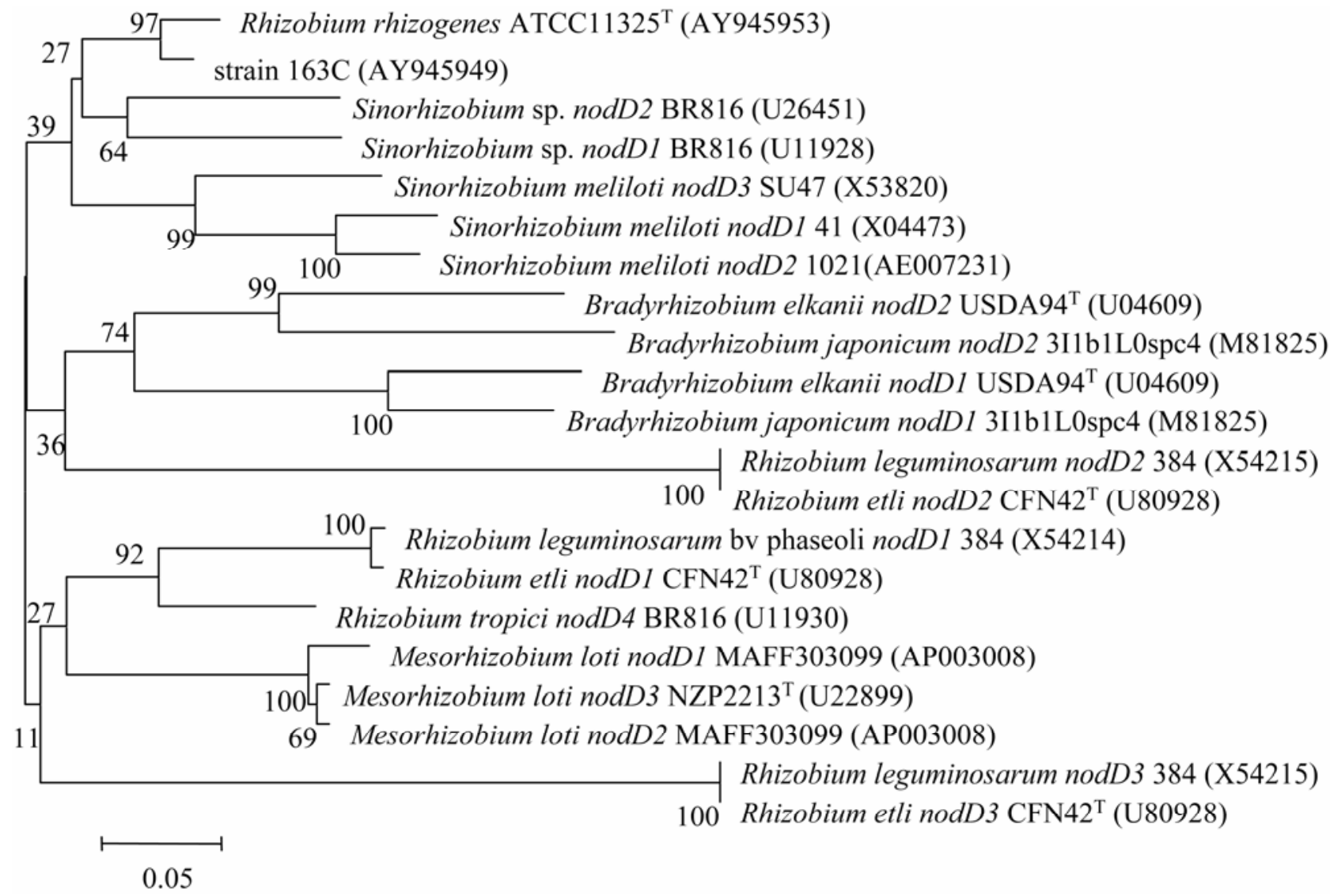

Fig. 6. Neighbor-joining tree of nodD gene sequences of the strains analyzed in this study and representative related strains from GenBank. Bootstrap values calculated for 1,000 replications are indicated. The analysis was based on 300 nucleotides. Bar, 5 nucleotide substitutions per 100 nucleotides. 
Lucas et al. 1995; van Rhijn et al. 1996) (Fig. 6). The close phylogenetic relationship of the nodD and nifH genes from the analyzed strains to those of symbiotic rhizobial strains raises the possibility that these strains nodulate legumes.

\section{Nodulation of $P$. vulgaris.}

In order to test the ability to nodulate legumes, we inoculated $P$. vulgaris with strains $163 \mathrm{C}$ and ATCC $11325^{\mathrm{T}}$. The re-

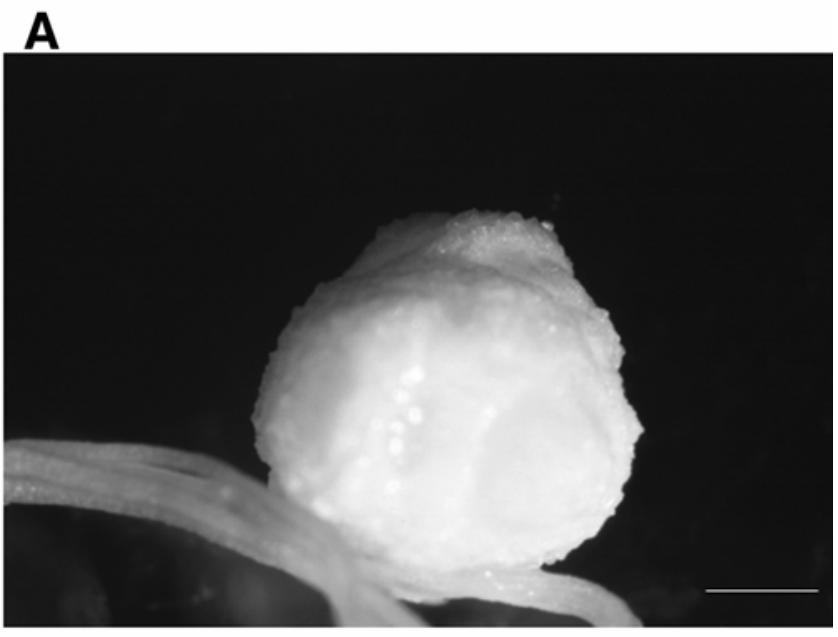

B
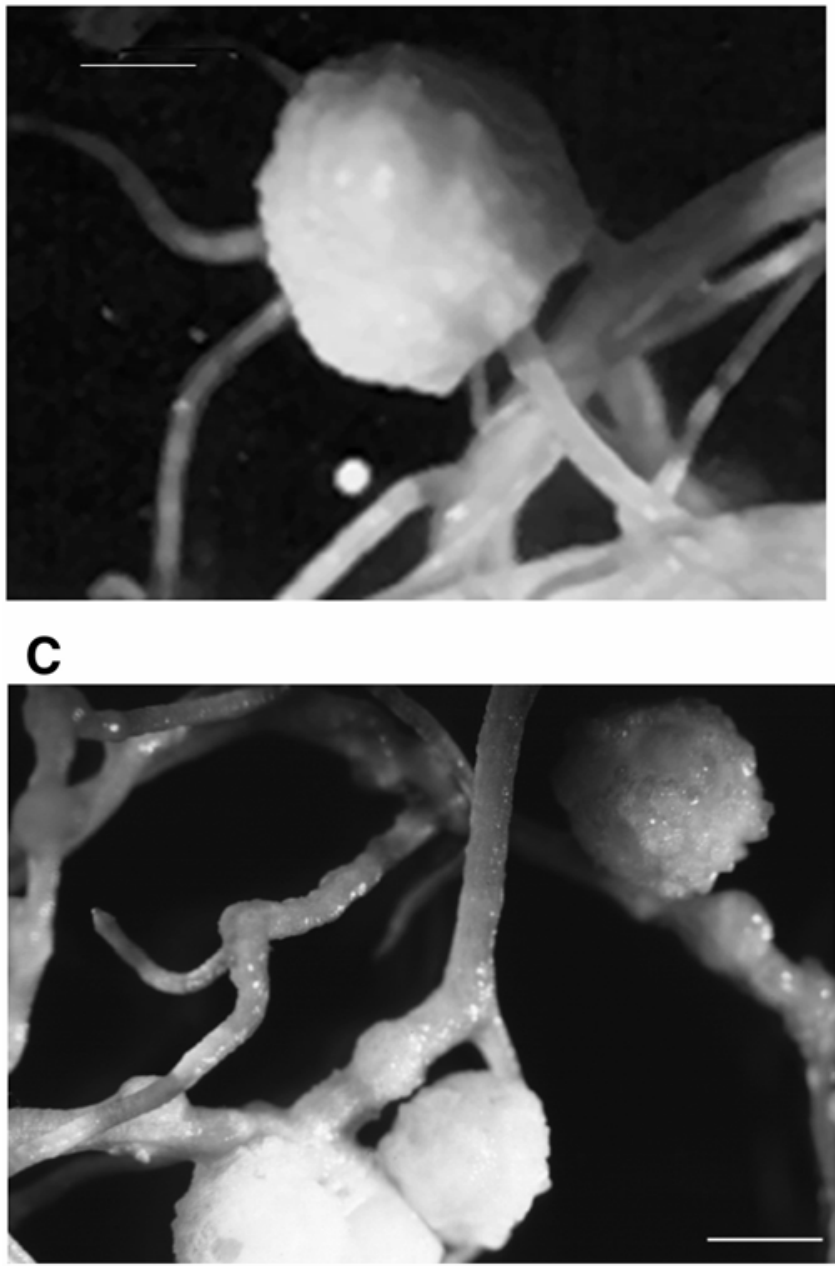

Fig. 7. Nodules induced by A, strain Rhizobium rhizogenes ATCC $11325^{\mathrm{T}}$, B, Rhizobium sp. $163 \mathrm{C}$, and C, $R$. etli $\mathrm{CFN} 42^{\mathrm{T}}$ in Phaseolus vulgaris roots. Bars, $0.4 \mathrm{~cm}$. sults (Fig. 6) indicate that both strains nodulated this legume. The external morphology of the nodules induced by these strains (Fig. 7A and B) was similar to that obtained with strain R. etli CFN42 ${ }^{\mathrm{T}}$ (Fig. 6C). The external color of these nodules was white and, in a transversal section, only a light pink color was detected (data not shown). The plants inoculated with strains $163 \mathrm{C}$ and ATCC $11325^{\mathrm{T}}$ have significantly lower numbers of nodules, dry matter, and $\mathrm{N}$ content than those inoculated with strain $R$. etli $\mathrm{CFN} 42^{\mathrm{T}}$, used as positive control (Table $1)$. The plants inoculated with strains $163 \mathrm{C}$ and $R$. rhizogenes showed a lighter green color than those inoculated with $R$. etli CFN42 ${ }^{\mathrm{T}}$, but had significantly higher dry matter and $\mathrm{N}$ content than uninoculated plants. Therefore, strains $163 \mathrm{C}$ and ATCC $11325^{\mathrm{T}}$ seem to be able to fix low amounts of $\mathrm{N}$ in $P$. vulgaris.

\section{DISCUSSION}

The genus Rhizobium currently includes fast-growing species able to induce hypertrophies in plants that may be nitrogen-fixing nodules, hairy roots, or tumors. The induction of these structures is determined by plasmid-borne genes that can be transferred in the rhizosphere. Nevertheless, to our knowledge, this transference has been reported among pathogenic and nonpathogenic strains from the same species (López-López et al. 1999; Stockwell et al. 1996) and from rhizobial species to nonrhizobial species (Chen et al. 2001; Moulin et al. 2001; Rivas et al. 2002; Sy et al. 2001; Trujillo et al. 2005; van Berkum et al. 2002; Vandamme et al. 2002). Therefore, until now, there are no reports on the transfer of virulence genes to a symbiotic species or vice versa under natural environmental conditions. Although some artificial transconjugants of $R$. tumefaciens carrying plasmids from the rhizobial strain CFN299 may nodulate Phaseolus spp. (Martínez et al. 1987), most of the artificial strains carrying pSym and pTi or pRi plasmids do not induce typical nodules and hairy roots or tumors (Hooykaas et al. 1981; Truchet et al. 1984; van Veen et al. 1989). Broothaerts and associates (2005) have just reported the induction of tumors by transconjugant strains of Rhizobium, Sinorhizobium, and Mesorhizobium; nevertheless, they did not test the nodulation of legumes by these strains.

Strain 163C, isolated several years ago from Prunus persica, is closely related to strain ATCC $11325^{\mathrm{T}}$ on the basis of its LMW RNA profile (Velázquez et al. 2001b). The high similarity (near $100 \%$ ) of the $16 \mathrm{~S}$ rRNA sequence of strain $163 \mathrm{C}$ to that of the type strain of the species $R$. rhizogenes confirms that it probably belong to this species. $R$. rhizogenes is widely known as a hairy root inducer (Kersters et al. 1973), although some strains from this species may form plant tumors (Sawada et al. 1993). This species forms a phylogenetic cluster within the genus Rhizobium together with species able to nodulate Phaseolus spp. (Fig. 1) which is different from that formed by other species of genus Rhizobium able to originate tumors, such as $R$. tumefaciens, $R$. rubi, or $R$. vitis. Nevertheless, all these species are able to produce plant hypertrophies due to

Table 1. Symbiotic characteristics of the Rhizobium strains from this study ${ }^{\mathrm{z}}$

\begin{tabular}{|c|c|c|c|}
\hline Treatment & $\begin{array}{l}\text { Nodules } \\
\text { per plant }\end{array}$ & $\begin{array}{l}\text { Shoot dry } \\
\text { matter }\end{array}$ & $\begin{array}{c}\text { Total N } \\
\text { (mg) }\end{array}$ \\
\hline Control without $\mathrm{N}$ & $0 \mathrm{a}$ & $470 \mathrm{a}$ & $9.4 \mathrm{a}$ \\
\hline R. rhizogenes ATCC $11325^{\mathrm{T}}$ & $8 \mathrm{~b}$ & $680 \mathrm{~b}$ & $15.0 \mathrm{~b}$ \\
\hline $163 \mathrm{C}$ & $9 \mathrm{~b}$ & $700 \mathrm{~b}$ & $15.4 \mathrm{~b}$ \\
\hline R. etli CFN42 ${ }^{\mathrm{T}}$ & $170 \mathrm{c}$ & $1,163 \mathrm{c}$ & $27.7 \mathrm{c}$ \\
\hline
\end{tabular}

${ }^{\mathrm{z}}$ Values from each column followed by the same letter are not signifycantly different from each other at $P=0.05$ according to Fisher's protected least significant differences. 
the presence of plasmids harboring virulence or symbiotic genes.

We reported previously that strains $163 \mathrm{C}$ and ATCC $11325^{\mathrm{T}}$ carry two megaplasmids (Velázquez et al. 2001b). In the present study, a third, larger plasmid was detected in both strains by taking the samples in an earlier growth phase than in the previous work. This seems to favor the detection of high plasmids in rhizobial and nonrhizobial species (Rivas et al. 2002). In addition, we have observed that these plasmids remain stable in the strains analyzed after many subcultures performed since their isolation several years ago.

Taking into account that $R$. rhizogenes ATCC $11325^{\mathrm{T}}$ is able to produce hairy roots (Kersters et al. 1973) and strain 163C was able to produce tumors in plants (Velázquez et al. 2001b), the presence of vir genes in some of the plasmids harbored by these strains was expected. The virA gene was located by Southern blot analysis of plasmid profiles in pRrh163Ca and pRrh11325a plasmids. The sequences of virA and virB genes are closely related to those of other strains from tumorigenic or hairy root-inducing species of Rhizobium. Nevertheless, whereas the virA and virB4 genes of strain ATCC $11325^{\mathrm{T}}$ showed differences from those of the other strains, in the case of strain $163 \mathrm{C}$ these genes were practically $100 \%$ homologous to those of strain $R$. tumefaciens C58. Although these results suggest that the pTi plasmid of strain $163 \mathrm{C}$ and $R$. tumefaciens C58 would be the same, more studies are necessary to establish this conclusion.

The partial sequences of nodD and nifH genes showed a close phylogenetic relationship with those of strains nodulating Phaseolus vulgaris, a promiscuous host nodulated by several rhizobial species (Herrera-Cervera et al. 1999; Martínez et al. 1987; Martínez-Romero 2003; Martínez-Romero et al. 1991; Michiels et al. 1998; Rogel et al. 2001; Velázquez et al. 2001a). The symbiotic ability of the strains analyzed here was confirmed by inoculation in $P$. vulgaris plants of both strains $163 \mathrm{C}$ and ATCC $11325^{\mathrm{T}}$, resulting in the formation of less effective nodules than those obtained with $R$. etli CFN42 ${ }^{\mathrm{T}}$. The fact that these strains elicited a low number of nodules and fixed only small amounts of nitrogen may indicate that $P$. vulgaris is not their natural host. This conclusion is further supported by the fact that the similarity of the symbiotic genes of our isolates with respect to those of strains nodulating Phaseolus spp. is much lower than $100 \%$.

Therefore, the results of this study show that there are natural strains of the genus Rhizobium which may be pathogenic for nonlegume plants and also endosymbionts for legumes. These results raise the possibility that an ancestral strain belonging to the genus Rhizobium carrying pSym plasmids acquired pTi- or pRi-type plasmids by lateral transfer. These possibilities are in agreement with the hypothesis posed by Paulsen and associates (2002) which postulated that an ancestral strain unable to establish relationships with other organisms evolved into animal pathogens such as Brucella spp. and plant pathogens or symbionts such as Rhizobium spp.

\section{MATERIALS AND METHODS}

\section{Strains and culture conditions.}

Strain 163C was isolated in a previous work from tumors of Prunus persica in Spain (Velázquez et al. 2001b) and strain $R$. rhizogenes ATCC $11325^{\mathrm{T}}$ was isolated from apple (Riker et al. 1930). Single isolates were used to obtain pure cultures for the analyses. Strains $163 \mathrm{C}$ and ATCC $11325^{\mathrm{T}}$ were grown on YMA medium (Vincent 1970). For DNA extraction and plasmid analysis, these strains and Sinorhizobium meliloti GR4 used as reference were incubated in TY liquid medium (Beringer 1974) and grown at $28^{\circ} \mathrm{C}$ and $180 \mathrm{rpm}$ for $24 \mathrm{~h}$.
DNA extraction and sequence analysis.

DNA was extracted as described previously (Rivas et al. 2001). The polymerase chain reaction (PCR) amplification and the sequencing of 16S rRNA and nifH and nodD genes of strains $163 \mathrm{C}$ and ATCC $11325^{\mathrm{T}}$ were carried out as described by Rivas and associates (2002) using the primers described by Zurdo-Piñeiro and associates (2004) for sequencing of the $16 \mathrm{~S}$ rRNA gene. The virA and virB4 genes were amplified and sequenced using the same conditions and the following primers pairs: virA1F, 5'-ATGAATGGAAGGTATTCACCG-3' and virA2R, 5'-GGCTCAGGCAGCTTCGCTGCG-3' ( $R$. tumefaciens virA gene, AE007923, positions 1 to 21 and 1,070 to 1,054, respectively); and viRB41F, 5'-CGCTCTWGCGCAAT ATHGC-3' and virB41R, 5'-GCCGCGATCCTTGTCGAAG-3' (R. tumefaciens virB4 gene, AE007923, positions 185 to 203 and 1,407 to 1,389 , respectively). The sequences obtained were compared with those from GenBank using the BLAST program (Alschul et al. 1990). Sequences were aligned using the ClustalW software (Thompson et al. 1997). The distances were calculated according to Kimura's two-parameter method (Kimura 1980) and phylogenetic trees were inferred using the neighbor-joining method (Saitou and Nei 1987). Bootstrap analysis was based on 1,000 resamplings. The MEGA2 package (Kumar et al. 2001) was used for all analyses.

\section{Plasmid profile analysis.}

The strains were incubated in TY medium at $25^{\circ} \mathrm{C}$ and 180 rpm until the culture reached a concentration of $1 \times 10^{6}$ cells $/ \mathrm{ml}$ and then the cells were collected for plasmid analysis by centrifuging $1.5 \mathrm{ml}$ of culture at $9,000 \times g$ for $5 \mathrm{~min}$. This analysis was performed according to Plazinski and associates (1985), except that the electrophoresis was performed at $2 \mathrm{~V}$ $\mathrm{cm}^{-1}$ for $90 \mathrm{~min}$, followed by $3 \mathrm{~V} \mathrm{~cm}^{-1}$ for $60 \mathrm{~min}$ and finally 6 $\mathrm{V} \mathrm{cm}{ }^{-1}$ for $4 \mathrm{~h}$. The pRmeGR4b (205-kb) and pRmeGR4a (175-kb) plasmids of S. meliloti GR4 (Toro and Olivares 1986) were used as molecular markers.

\section{DNA hybridization.}

The probes for Southern hybridization (Southern 1975) were obtained by PCR using oligonucleotide primers designed in this study to amplify a fragment of the virA gene (discussed above) and primers designed previously to amplify fragments of the nodD and nifH genes (Rivas et al. 2002).

The PCR-amplified fragments of nifH, nodD, and virA were digoxigenin (DIG) labeled with the DIG DNA Labeling Kit (Roche Diagnostics Corp., Branchburg, NJ, U.S.A.) following the manufacturer's instructions and used as probes. Hybridization was detected with the DIG Nucleic Acid Detection Kit (Boehringer Mannheim, Indianapolis, IN, U.S.A.), using 5bromo-4-chloro-3-indolyl phosphate and nitroblue tetrazolium as substrates for alkaline phosphatase.

\section{Nodulation tests.}

Surface-sterilized seeds of Phaseolus vulgaris were germinated axenically in petri dishes. Seedlings were transferred to pots with sterile vermiculite and watered with autoclaved nitrogen-free Rigaud and Puppo (1975) nutrient solution. Five plants were inoculated with $1 \mathrm{ml}$ each of a suspension of strains $163 \mathrm{C}$ and ATCC $11325^{\mathrm{T}}$ containing $8 \times 10^{8}$ cells $/ \mathrm{ml}$. The inoculated plants were placed in a plant growth chamber with mixed incandescent and fluorescent lighting (400 microeinsteins $\mathrm{m}^{-2} \mathrm{~s}^{-1}$; 400 to $700 \mathrm{~nm}$ ), programmed for a $16-\mathrm{h}$ photoperiod, day-night cycle, with a constant temperature varying from 25 to $27^{\circ} \mathrm{C}$, and 50 to $60 \%$ relative humidity. Strain $R$. etli CFN42 ${ }^{\mathrm{T}}$ was used as positive control. The negative controls were noninoculated $P$. vulgaris plants. Plants were watered with free-nitrogen Rigaud and Puppo solution. After 6 weeks, 
the strains from this study were isolated from nodules that were counted and the dry weight of the aerial part of the common bean plants was determined. Plant $\mathrm{N}$ content was measured according to the A.O.A.C. methods (Johnson 1990). The data obtained were analyzed by one-way analysis of variance, with the mean values compared using Fisher's protected least significant differences $(P=0.05)$.

\section{ACKNOWLEDGMENTS}

This work was supported by Junta de Castilla y León and MCYT of Spain. The authors thank I. Geldart for revising the English version of the manuscript.

\section{LITERATURE CITED}

Alschul, S. F., Gish, W., Miller, W., Myers, E. W., and Lipman, D. J. 1990. Basic local alignment search tool. J. Mol. Biol. 215:403-410.

Berger, B. R., and Christie, P. J. 1993. The Agrobacterium tumefaciens virB4 gene product is an essential virulence protein requiring an intact nucleoside triphosphate-binding domain. J. Bacteriol. 175(6):17231734.

Beringer, J. E. 1974. R factors transfer in Rhizobium leguminosarum. J. Gen. Microbiol. 84:188-198.

Broothaerts, W., Mitchell, H. J., Weir, B., Kalnes, S., Smith, L. M. A., Yang, W., Mayer, J. E., Roa-Rodríguez, C., and Jefferson, R.A. 2005. Gene transfer to plants by diverse species of bacteria. Nature 433:629633.

Chen, W. M., Laevens, S., Lee, T. M., Coenye, T., de Vos, P., Mergeay, M., and Vandamme, P. 2001. Ralstonia taiwanensis sp. nov., isolated from root nodules of Mimosa species and sputum of a cystic fibrosis patient. Int. J. Syst. Evol. Microbiol. 51:1729-1735.

Dang, T. A., and Christie, P. J. 1997. The VirB4 ATPase of Agrobacterium tumefaciens is a cytoplasmic membrane protein exposed at the periplasmic surface. J. Bacteriol. 179:453-462.

Endoh, H., Hirayama, T., Aoyama, T., and Oka, A. 1990. Characterization of the virA gene of the agropine-type plasmid pRiA4 of Agrobacterium rhizogenes. FEBS (Fed. Eur. Biol. Soc.) Lett. 271:28-32.

Farrand, S. K., van Berkum, P. B., and Oger, P. 2003. Agrobacterium is a definable genus of the family Rhizobiaceae. Int. J. Syst. Evol. Microbiol. 53:1681-1687.

Goodner, B., Hinkle, G., Gattung, S., Miller, N., Blanchard, M., Qurollo, B., Goldman, B. S., Cao, Y., Askenazi, M., Halling, C., Mullin, L., Houmiel, K., Gordon, J., Vaudin, M., Iartchouk, O., Epp, A., Liu, F., Wollam, C., Allinger, M., Doughty, D., Scott, C., Lappas, C., Markelz, B., Flanagan, C., Crowell, C., Gurson, J., Lomo, C., Sear, C., Strub, G., Cielo, C., and Slater, S. 2001. Genome sequence of the plant pathogen and biotechnology agent Agrobacterium tumefaciens C58. Science 294:2323-2328.

Haukka, K., Lindström, K., and Young, P. 1998. Three phylogenetic groups of nodA and nifH genes in Sinorhizobium and Mesorhizobium isolates from leguminous trees growing in Africa and Latin America. Appl. Environ. Microbiol. 64:419-426.

Hernández-Lucas, I., Segovia, L., Martínez-Romero, E. and Pueppke, S. G. 1995. Phylogenetic relationships and host range of Rhizobium spp. that nodulate Phaseolus vulgaris L. Appl. Environ. Microbiol. 61:27752779

Herrera-Cervera, J. A., Caballero-Mellado, J., Laguerre, G., Tichy, H. V., Requena, N. Amarger, N., Martínez-Romero, E., Olivares, J., and Sanjuán, J. 1999. At least five rhizobial species nodulate Phaseolus vulgaris in a Spanish soil. FEMS (Fed. Eur. Microbiol. Soc.) Microbiol. Ecol. 30:87-97.

Hooykaas, P. J. J., van Brussel, A. A. N., den Dulk-Ras, H., van Slogteren, G. M. S., and Schilperoort, R. A. 1981. Sym plasmid of R. trifolii expressed in different rhizobial species and in Agrobacterium tumefaciens. Nature 276:634-636.

Jin, S., Roitsch, T., Ankenbauer, R. G., Gordon, M. P., and Nester, E. W. 1990. The VirA protein of Agrobacterium tumefaciens is autophosphorylated and is essential for vir gene regulation. J. Bacteriol. $172: 525-530$.

Johnson, F. J. 1990. Detection method of nitrogen in fertilizers. Pages 1719 in: Methods of Analysis of the Association of Official Analytical Chemists. K. Elrich, eds. Association of Official Analytical Chemists, Arlington, VA, U.S.A.

Kersters, K., De Ley, J., Sneath, P. H. A., and Sackin, M. 1973. Numerical taxonomy analysis of Agrobacterium. J. Gen. Microbiol. 78:227-239.

Kimura, M. 1980. A simple method for estimating evolutionary rates of base substitutions through comparative studies of nucleotide sequences.
J. Mol. Evol. 16:111-120.

Kumar, S., Tamura, K., Jakobsen, I. B., and Nei, M. 2001. Molecular Evolutionary Genetics Analysis Software. Arizona State University, Tempe, AZ, U.S.A.

Laguerre, G., Nour, S. M., Macheret, V., Sanjuán, J., Drouin, P., and Amarger, N. 2001. Classification of rhizobia based on nodC and nifH analysis reveals a close phylogenetic relationship among Phaseolus vulgaris symbionts. Microbiology (Read.) 147:981-993.

Lee, Y. W., Jin, S., Sim, W. S., and Nester, E. W. 1995. Genetic evidence for direct sensing of phenolic compounds by the VirA protein of Agrobacterium tumefaciens. Proc. Natl. Acad. Sci. U.S.A. 92:12245-12249.

Liang, Y., Aoyama, T., and Oka, A. 1998. Structural characterization of the virB operon on the hairy-root-inducing plasmid A4. DNA Res. 5:87-93

López-López, M. J., Vicedo, B., Orellana, N., Piquer, J., and López, M. M. 1999. Behavior of a virulent strain derived from Agrobacterium radiobacter strain $\mathrm{K} 84$ after spontaneous $\mathrm{Ti}$ plasmid acquisition. Phytopathology 89:286-292.

Martínez, E., Palacios, R., and Sánchez, F. 1987. Nitrogen-fixing nodules induced by Agrobacterium tumefaciens harboring Rhizobium phaseoli plasmids. J. Bacteriol. 169:2828-2834

Martínez-Romero, E. 2003. Diversity of Rhizobium-Phaseolus vulgaris symbiosis: overview and perspectives. Plant Soil 252:11-23.

Martínez-Romero, E., Segovia, L., Mercante, F. M., Franco, A., Graham, P., and Pardo, M. A. 1991. Rhizobium tropici, a novel species nodulating Phaseolus vulgaris L. beans and Leucaena sp. trees. Int. J. Syst. Bacteriol. 41:417-426.

Michiels, J., Dombrecht, B., Vermeiren, N., Xi, C., Luyten, E., and Vanderleyden, J. 1998. Phaseolus vulgaris is a non-selective host for nodulation. FEMS (Fed. Eur. Microbiol. Soc.) Microbiol. Ecol. 26:193205.

Moriguchi, K., Maeda, Y., Satou, M., Hardayani, N. S. N., Kataoka, M., Tanaka, N., and Yoshida, K. 2001. The complete nucleotide sequence of a plant-root inducing (Ri) plasmid indicates its chimeric structure and evolutionary relationship between tumor-inducing (Ti) and symbiotic (Sym) plasmids in Rhizobiaceae. J. Mol. Biol. 307:771-784.

Moulin, L., Munive, A, Dreyfus, B., and Boivin-Masson, C. 2001. Nodulation of legumes by members of $\beta$-subclass of Proteobacteria. Nature 411:948-950

Paulsen, I. T., Seshadri, R., Nelson, K. E., Eisen, J. A., Heidelberg, J. F., Read, T. D., Dodson, R. J., Umayam, L., Brinkac, L. M., Beanan, M. J., Daugherty, S. C., Deboy, R. T., Durkin, A. S., Kolonay, J. F., Madupu, R., Nelson, W. C., Ayodeji, B., Kraul, M., Shetty, J., Malek, J., van Aken, S. E., Riedmuller, S., Tettelin, H., Gill, S. R., White, O., Salzberg, S. L., Hoover, D. L., Lindler, L. E., Halling, S. M., Boyle, S. M., and Fraser, C. M. 2002. The Brucella suis genome reveals fundamental similarities between animal and plant pathogens and symbionts. Proc. Natl. Acad. Sci. U.S.A. 99:13148-13153.

Plazinski, J., Chen, Y. H., and Rolfe, B. G. 1985. General method for the identification of plasmid species in fast-growing soil microorganisms. Appl. Environ. Microbiol. 48:1001-1003.

Rigaud, J., and Puppo, A. 1975. Indol-3-acetic catabolism by soybean bacteroids. J. Gen. Microbiol. 88: 223-228.

Riker, A. J., Banfield, W. M., Wright, W. H., Keitt, G. W., and Sagen, H. E. 1930. Studies on infectious hairy-root of nursery apple trees. J. Agric Res. 41:507-540.

Rivas, R., Velázquez, E., Valverde, A., Mateos, P. F., and Martínez-Molina, E. 2001. A two primers random amplified polymorphic DNA procedure to obtain polymerase chain reaction fingerprints of bacterial species. Electrophoresis 22:1086-1089.

Rivas, R., Velázquez, E., Willems, A., Vizcaino, N., Subba-Rao, N. S., Mateos, P. F., Gillis, M., Dazzo, F. B., and Martínez-Molina, E. 2002. A new species of Devosia that forms a unique nitrogen-fixing root-nodule symbiosis with the aquatic legume Neptunia natans (L.f.) druce. Appl. Environ. Microbiol. 68:5217-5222.

Rogel, M. A., Hernández-Lucas, I., Kuykendall, L. D., Balkwill, D. L., and Martínez-Romero, E. 2001. Nitrogen-fixing nodules with Ensifer adhaerens harboring Rhizobium tropici symbiotic plasmids. Appl. Environ. Microbiol. 67:3264-3268.

Saitou, N., and Nei, M. 1987. A neighbour-joining method: a new method for reconstructing phylogenetics trees. Mol. Biol. Evol. 44:406-425.

Satuti, N., Moriguchi, K., Sato, M., Kataoka, M., Maeda, Y., Tanaka, N., and Yoshida, K. 2000. Genome structure of Ri plasmid (3). Sequencing analysis of the vir region of pRi1724 in Japanese Agrobacterium rhizogenes. Nucleic Acids Symp. Ser. 44:95-96.

Sawada, H., Ieki, H., Oyaizu, H., and Matsumoto, S. 1993. Proposal for rejection of Agrobacterium tumefaciens and revised descriptions for the genus Agrobacterium and for Agrobacterium radiobacter and Agrobacterium rhizogenes. Int. J. Syst. Evol. Microbiol. 43:694-702.

Southern, E. M. 1975. Detection of specific sequences among DNA fragments separated by gel electrophoresis. J. Mol. Biol. 98:503-517. 
Stockwell, V. O., Kawalek, M. D., Moore, L. W., and Loper, J. E. 1996. Transfer of pAgK84 from the biocontrol agent Agrobacterium radiobacter K84 to A. tumefaciens under field conditions. Phytopathology 86:31-37.

Suominen, L., Roos, C., Lortet, G., Paulin, L., and Lindström, K. 2001. Identification and structure of the Rhizobium galegae common nodulation genes: evidence for horizontal gene transfer. Mol. Biol. Evol. 18:907-916.

Sy, A., Giraud, E., Jourand, P., García, N., Willems, A., de Lajudie, A. P., Prin, Y. Neyra, M., Gillis, M., Boivin-Masson, C., and Dreyfus, B. 2001. Methylotrophic Methylobacterium bacteria nodulate and fix nitrogen in symbiosis with legumes. J. Bacteriol. 183:214-220.

Thompson, J. D., Gibson, T. J., Plewniak, F., Jeanmougin, F., and Higgins, D. G. 1997. The ClustalX Windows interface: flexible strategies for multiple sequence alignment aided by quality analysis tools. Nucleic Acid Res. 24:4876-4882.

Toro, N., and Olivares, J. 1986. Characterization of a large plasmid of Rhizobium meliloti involved in enhancing nodulation. Mol. Gen. Genet. 202:331-335.

Truchet, G., Rosenberg, C., Vasse, J., Julliot, J.-S., Camut, S., and Denarie, J. 1984. Transfer of Rhizobium meliloti pSym genes into Agrobacterium tumefaciens: Host-specific nodulation by atypical infection. J. Bacteriol. 157:134-142.

Trujillo, M. E., Willems, A., Abril, A., Planchuelo, A. M., Rivas, R., Ludeña, D., Mateos, P. F., Martínez-Molina, E., and Velázquez, E. 2005. Nodulation of Lupinus by strains of the new species Ochrobactrum lupini sp. nov. Appl. Environ. Microbiol. 71:1318-1327.

van Berkum, P., and Eardly, B. 2002. The aquatic budding bacterium Blastobacter denitrificans is a nitrogen fixing symbiont of Aeschynomene indica. Appl. Environ. Microbiol. 68:1132-1136.

Vandamme, P., Goris, J., Chen, W. M., de Vos, P., and Willems, A. 2002. Burkholderia tuberum sp. nov. and Burkholderia phymatum sp. nov., nodulate the roots of tropical legumes. Syst. Appl. Microbiol. 25:507512 van Rhijn, P. J., Feys, B., Verreth, C., and Vanderleyden, J. 1993. Multiple copies of nodD in Rhizobium tropici CIAT899 and BR816. J. Bacteriol. 175:438-447.

van Rhijn, P., Luyten, E., Vlassak, K., and Vanderleyden, J. 1996. Isolation and characterization of a pSym locus of Rhizobium sp. BR816 that extends nodulation ability of narrow host range Phaseolus vulgaris symbionts to Leucaena leucocephala. Mol. Plant Microbe Interact. 9:74-77.

van Veen, R. J. M., den Dulk-Ras, H., Schilperoort, R. A., and Hooykaas, P. J. J. 1989. Ti plasmid containing Rhizobium meliloti are non-tumorigenic on plants, despite proper virulence gene induction and T-strand formation. Arch. Microbiol. 153:85-98.

Velázquez, E., Martínez-Romero, E., Rodríguez-Navarro, D. N., Trujillo, M. E. , Daza, A., Mateos, P. F., Martinez-Molina, E., and van Berkum, P. 2001a. Characterization of rhizobial isolates of Phaseolus vulgaris by Staircase Electrophoresis of Low Molecular Weight RNA. Appl. Environ. Microbiol. 67:1008-1010.

Velázquez, E., Palomo, J. L., Lastra, B., Mateos, P., García-Benavides, P., and Martínez-Molina, E. 2001b. Rapid identification of Agrobacterium species by staircase electrophoresis of low molecular weight RNA profiles. Eur. J. Plant Pathol.. 107:931-938.

Vincent J. M. 1970. The cultivation, isolation and maintenance of rhizobia Pages 1-13 in: A Manual for the Practical Study of Root-Nodule. J. M. Vincent, ed. Blackwell Scientific Publications, Oxford.

Young, J. M., Kuykendall, L. D., Martínez-Romero, E., Kerr, A., and Sawada, H. 2001. A revision of Rhizobium Frank 1889, with an emended description of the genus, and the inclusion of all species of Agrobacterium Conn 1942 and Allorhizobium undicola de Lajudie et al. 1998 as new combinations: Rhizobium radiobacter, $R$. rhizogenes, $R$ rubi, $R$. undicola and $R$. vitis. Int. J. Syst. Evol. Microbiol. 51:89-103.

Zurdo-Piñeiro, J. L., Velázquez, E., Lorite, M. J., Brelles-Mariño, G. Schröder, E. C., Bedmar, E. J., Mateos, P. F., and Martínez-Molina, E. 2004. Identification of fast-growing rhizobia nodulating tropical legumes from Puerto Rico as Rhizobium gallicum and Rhizobium tropici. Syst. Appl. Microbiol. 27:469-477. 